\title{
Understanding ICT Based Advantages: A Techno Savvy Case Study
}

\author{
Karyn Rastrick \\ University of Waikato \\ Management School, Hamilton, \\ New Zealand
}

\author{
James Corner \\ University of Waikato \\ Management School, Hamilton, \\ New Zealand, \\ and Bordeaux Management \\ School, Bordeaux, France
}

karyn@waikato.ac.nz

jcorner@waikato.ac.nz

\begin{abstract}
Information and communication technologies (ICTs) increasingly are being linked to organisational value. However, current research tends to examine these resources in an uncoupled way despite numerous calls for work which examines ICTs in a more integrated way. This research addresses this gap by investigating how ICTs are successfully combined with other resources in the context of an exemplar organisation. The resource based view (RBV) is used as a framework to guide this research. The RBV is an appropriate lens due to its focus on resources and capabilities as sources of advantage. This research employs an interpretive case study design based in an organisation with a long history of innovation and success with regard to ICTs. An integrated model of advantage is presented based on two distinct groupings of capabilities. In essence, this research demonstrates how the total ownership of ICTs, within the case studied, presents a potential advantage. The advantage is realised through the combination of capabilities and the inclusive approach to ICT development employed in the case organisation. This research has important implications for theory and practice. While many individual sources of advantage have been empirically examined, this research provides one of the first in-depth case studies that identify integrated capabilities. Understanding such sources of advantage will help practitioners better understand and protect key organisational capabilities to sustain or extend competitive advantages.
\end{abstract}

Keywords: Information Communication Technologies; Integrated Capabilities, Resource Based View, Case Study

\section{Introduction}

Material published as part of this publication, either on-line or in print, is copyrighted by the Informing Science Institute. Permission to make digital or paper copy of part or all of these works for personal or classroom use is granted without fee provided that the copies are not made or distributed for profit or commercial advantage AND that copies 1) bear this notice in full and 2) give the full citation on the first page. It is permissible to abstract these works so long as credit is given. To copy in all other cases or to republish or to post on a server or to redistribute to lists requires specific permission and payment of a fee. Contact Publisher@InformingScience.org to request redistribution permission.
Due to the emergence and widespread use of information and communication technologies (ICTs) organisations have faced many changes in their business practices in recent times, in particular the last two decades. In this time period, organisations have invested large amounts of time and money into the adoption of ICTs. While prior research has tended to focus on individual resources and capabilities, such as capital 
requirement or proprietary technology (Mata, Fuerst, \& Barney, 1995), there is an emerging stream of research which recognises that ICTs have limited value when used in isolation. As such, value is significantly enhanced when resources are combined with other organisational resources and capabilities (Mata et al., 1995; Powell \& Dent-Micallef, 1997; Ray, Barney, \& Muhanna, 2004). So despite large spending it appears that research to date has failed to understand ICT investments and many questions remain unanswered (Rastrick, 2009).

Acknowledging the systemic approach required to study ICTs, scholars of information systems have recognised the need for better ways to examine them (Mooney, Gurbaxani, \& Kraemer, 1995; Ray et al., 2004). Moreover, there have been calls for further review and testing of ICTs utilising frameworks from other literatures, like the resource based view (RBV) from the strategic management literature (Bharadwaj, 2000; Powell \& Dent-Micallef, 1997). The RBV is an appropriate framework to guide this research due to its focus on resources and capabilities. The RBV argues that a firm's source of competitive advantage lies with the resources and capabilities it owns and controls and the unique way in which a firm bundles them together (Barney, 1991; Penrose, 1959; Wernerfelt, 1984). This paper examines ICTs in their environment using an RBV lens to address the gap in current research. The rest of this paper outlines past research, the research design employed in this research, and presents and discusses integrated capabilities leading to sustained success in a New Zealand company. Finally, a summary is provided along with implications for future research.

\section{Past Research}

Current literature shows that there is growing support for the positive relationship between ICTs and advantage (Lin \& Lin, 2006; Melville, Kraemer, \& Gurbaxani,, 2004; Menon, Lee, \& Eldenburg, 2000; Porter \& Millar, 1998), that is, ICTs have value to organisational advantage. Researchers have attempted to identify sources of advantage and, more importantly, sources of ICT based advantage (Mata et al., 1995; Ray et al., 2004). The RBV asserts that ownership and control of strategic resources and capabilities determines which organisations will earn superior profits and enjoy a position of competitive advantage over others. Moreover current RBV research provides a new lens for examining the combination of resources and capabilities. There has been much discussion of the terms resources and capabilities; see Barney (1991) and Peteraf (1993) for discussion. Hult and Ketchen (2001) posit that it is the combination of resources within organisations that collectively contribute to competitive advantage. The researchers suggest market orientation, entrepreneurship, innovation, and organisational learning collectively contribute to the creation of unique resources. Similarly, Jones and George (1998) have examined cooperation, teamwork, and trust by viewing these resources or capabilities in a coupled way. Newer streams of research linked to the RBV, such as the dynamic capabilities approach and the knowledge based view, also provide insights into new places to look for valuable resource and capability combinations. More specifically, dynamic capabilities research suggest that value is gained when resources are utilised in coupled and innovative ways (Eisenhardt \& Martin, 2000; Miller, 2003; Teece, Pisano, \& Shuen, 1997). The knowledge based view also offers suggestions of what is valuable to organisations. More specifically the knowledge based view suggests knowledge resources are a critical part of interconnected resources or capabilities and, hence, valuable to organisations (Liebeskind, 1996; Spender, 1996a, 1996b; Wright, Dunford, \& Snel, 2001). While theoretical discussion is evident, empirical research that examines resources combinations which lead to a competitive advantage in the ICT context is currently limited.

Another gap in current research examining ICT resources relates to the methodologies employed. Traditionally such studies have employed quantitative methods such as large scale surveys (Dewan \& Kraemer, 1998; Rai, Patnayakuni, \& Patnayakuni, 1997). There are numerous calls to employ more qualitative research methods (Chan, 2000; Powell \& Dent-Micallef, 1997; Rouse \& 
Daellenbach, 1999). Resource based advantages are known to be organisational in origin and complex. Therefore, if the resources we seek to examine are so embedded in organisations, how can we seek to analyse them if not by being in organizations? What is needed is the use of indepth fieldwork in organisations such as a case study approach. In her review of the information technology field Chan (2000) also recognised that the field may not be fully understood without more qualitative contributions to the conversation.

Numerous examples of how single (or uncoupled) resources may lead to advantage can be found in the literature. For instance, Ray et al. (2004) suggest that a service climate and managerial IT knowledge are positively related to customer service performance. In an earlier study Mata et al. (1995) concluded that IS management is likely to be a source of competitive advantage. However many resources and capabilities do not function in isolation. Several researchers acknowledge there is a need to understand how more complex systemic resources such as ICTs might lead to an advantage (Mooney et al., 1995; Ray et al., 2004). This research, therefore, examines ICT resources in a more systemic way employing a qualitative research method. Specifically this research aims to utilise the RBV to address the following research questions: What are the sources of ICT advantage? How are ICT resources combined with other resources to create valuable resources and capabilities?

\section{Research Design}

The research was conducted employing a single case study design utilising interviews, observation, and documents. A case study method was deemed appropriate because it is consistent with the research questions, which are based around 'understanding' sources of advantage in organisations. While in organisations was not specifically outlined in the research questions, the RBV informed this research suggesting organisations should be the focus. A resource based advantage by definition implies that advantages are organisational in origin and complex (Rouse \& Daellenbach, 1999). A case study approach is advised in such circumstances when the phenomenon examined is complex and, therefore, difficult to separate from its organisational context (Langley, 1999; Pettigrew, 1992; Yin, 2003). The research case was chosen for its unique situation in reference to performance and ICTs and, in particular, for the consistent records of above average performance (hence suggesting value is gained within the organisation) and the unique way in which ICTs are developed and used in the organisation. (The organisation is hereafter known as ABC.) Customer satisfaction is a commonly used non-financial measure of performance within the sector $\mathrm{ABC}$ operates in. As such, regular surveys canvas the views of customers with respect to customer satisfaction. At the time of this research $\mathrm{ABC}$ has had the highest proportion of satisfied or very satisfied customers of the major players in their industry since the commencement of the survey (six years prior). While ABC is the smallest of the major players in the industry, it has the prestige position of the highest increase in net profit after tax, underlying performance and total assets in recent times. For instance in $2006, \mathrm{ABC}$ had a $17 \%$ increase in net profit after tax compared with a sector average of $11 \%$. The organisation has also historically been a high investor in ICTs. The service based nature of ABC's business also means that it is reliant on ICTs. $\mathrm{ABC}$ is a major player in their industry, having approximately 4,000 employees.

The data collection took place over an eight month period, which allowed an examination of the activities and decisions relating to a three phased customer relationship management (CRM) development project. Fifteen interviews were undertaken with interviewees who had a detailed knowledge of the development, implementation, and use of ICTs. Interviewees included senior managers, project managers, project team members, and end users of the CRM system. A more detailed description of the empirical base of this research can be found in Appendix A. Interviewees were asked to tell their own story about their role in ICT projects. A review of the relevant literature was also used in an ongoing way as a guide in developing further prompting ques- 
tions. For example, sources of advantage posed or identified from other studies were used as discussion points in the interview process (e.g., Yeoh and Roth's (1999) resource based study of critically important resources). The interview process was semi-structured, which allowed the use of probing questions which was deemed important for this type of research. Further details of the seed questions can be found in Appendix B. Seven observation sites used in the data collection process included natural working environments, training sessions, user groups, and steering group meetings. Finally, fourteen sources of public and private documents were reviewed including $\mathrm{ABC}$ 's annual reports, meeting minutes, scoping reports, and communication videos. Further details of the observations and documents can also be found in Appendix A.

The data analysis technique used in this research was an adaption of grounded theory (Strauss \& Corbin, 1998). More specifically, the grounded theory process involved three coding stages: open coding (i.e., the analytical process used to apply concepts to the data), axial coding (i.e., reassembling data into categories and subcategories), and selective coding (i.e., the process of refining the categories and refining theory) (Strauss \& Corbin, 1998). Further details and an example of the grounded theory process are provided in Appendix C.

Deciding on when to finalise the theory and discontinue looking for new data occurred when theoretical saturation was achieved (Strauss \& Corbin, 1998). Theoretical saturation is the point during data analysis when the researcher finds no new concepts, categories, or new variations of properties and dimensions (Strauss \& Corbin, 1998). Theoretical saturation is not a standalone concept; it is closely intertwined with theoretical sampling and constant comparison - techniques also employed in the use of grounded theory in this research. More precisely, theoretical saturation is reached when theoretical sampling provides nothing new to the coding process. That is, theoretical sampling (or collecting more data to refine the emergent theory) is continued until the analysis of the data (which is undertaken in parallel to the collection of the data) provides nothing new to the theoretical scheme being developed. In the words of Strauss and Corbin, saturation means collecting data until "(a) no new or relevant data seem to emerge regarding a category, (b) the category is well developed in terms of its properties and dimensions demonstrating variation, and (c) the relationship among categories are well established and validated" (1998, p 212). Note that Strauss and Corbin are not referring to validation in the statistical sense of the word. Rather, the researchers are referring to the process in which analysts constantly compare their work in progress against data collected, then make modifications or additions as required. This validation process continues until the emergent theory is arrived at.

\section{Integrated Capabilities at ABC}

The analysis of the data resulted in a number of resources (615) being linked to value at ABC. The resources were then further examined leading to 87 unique resources. That is, resources were regrouped linking similar resources until 87 unique or significantly different resources were identified. The process in which this was done is illustrated and discussed in Appendices $\mathrm{C}$ and D. Under closer examination, it became clear to the researchers that the resources at ABC did not exist in isolation but in a myriad of complex interrelationships. In particular, two distinct types of resources were identified as a result of the grounded theory analysis. The first were resources which had an effect on $\mathrm{ABC}$ 's information systems development at a particular point in time (i.e., a point in time in the life of a product or service) and the second were those that affected the whole life of the information system (i.e., at each stage in the life of a product or service). In line with these distinct types of resources the researchers grouped resources into two constructs that together form an integrated model of advantage at $\mathrm{ABC}$. The first construct is termed lifecycle capabilities and the second embedded foundational capabilities. 
Lifecycle capabilities represent key actions that contribute to successful information system processes at ABC. The construct is made up of six linear capabilities that form a continuous cycle of development of information systems (shown in Figure 1).

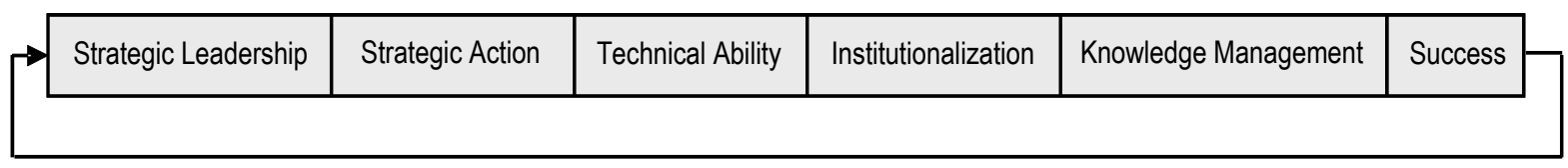

Figure 1: Lifecycle capabilities at $\mathrm{ABC}$

The first capability, strategic leadership, involves the high level initiation, alignment, and leadership involved in information system projects. As such, it encompasses the overall strategic direction of the organisation and alignment of high and lower level plans, as well as coordination of planning with other business divisions. Strategic leadership also involves an element of outward focus, sustaining belief, and ownership from the top level management, as well as providing a clear and supportive process.

Strategic action reflects the key elements of change, for instance, it involves promoting idea generation and capturing ideas within $\mathrm{ABC}$, as well as ensuring processes for realisation of change. It is a natural follow from strategic leadership in that it allows the progression of bigger picture ideas and helps to create operational projects ready to be developed. While sometimes ideas are generated at this stage, other projects are simply ones of reengineering current projects.

Part of realising change involves utilising technical ability. This stage encompasses adding a degree of agility in the product and process, as well as having the required technical knowledge of rules and processes of particular vintages of technology.

Institutionalisation is the next capability in the lifecycle. The essence of this stage is maintaining alignment and awareness of staff involved in projects, along with ensuring a continued level of commitment to projects at hand. An element of internal and external marketing also helps to provide a positive information flow supporting this stage.

Knowledge management involves the capture, active management, and promotion of knowledge. This involves creating a codified body of knowledge, identifying gaps in skill sets, and continuously improving processes.

The last stage of the cycle, success, reflects the role of real (for instance, external awards) and perceived (for instance, marketing and the halo effect seen from external awards) success has in reinforcing the lifecycle by adding support for strategic leadership, strategic action, and so forth through the whole lifecycle. Further details of the resources that contributed to each of the six capabilities can be seen in the larger study (Rastrick, 2009).

The combined effect of the integration of these capabilities outlines the way in which resources associated with information systems are developed at ABC. That is, lifecycle capabilities are valuable, strategic, technological, and organisational capabilities fundamental to the successful development of information systems. The capabilities are built over time from experiences, knowledge, and skills embedded at ABC. The capabilities evolve as learning from each project is fed back into the lifecycle, for instance, learning from experiences regarding ways of working and interacting changes capabilities over time. Therefore, capabilities are built on learning from historical projects. ABC's capabilities change and evolve. However, the way in which this happens is beyond the scope of this research. What is significant to this research is that there is collaboration and knowledge sharing that influences how capabilities are interrelated. As participants in a development process undertake a project they learn at each stage, individually, as well as at group 
and organisational levels. This learning in turn, feeds back and changes the process (and therefore capabilities evolve based on such learning).

While the capabilities that form the lifecycle are presented as a series of independent stages undertaken in a cyclic manner, it must be noted that the lifecycle is not rigid, nor are the stages independent of each other. Each of the stages is interconnected. Multiple projects may be undertaken at the same time and each of the stages can occur in a fluid manner.

The second construct, embedded foundational capabilities, is a group of key organisational capabilities that are seen to contribute to the success of $A B C$ across time (seen in Figure 2). That is, these capabilities do not have an effect at a point in time unlike in lifecycle capabilities. Rather, embedded foundational capabilities have an effect across the conception, development, and implementation of information systems. The name of this group of capabilities reflects the deeply embedded nature of these organisational capabilities. That is, each of the capabilities is fundamentally linked to other capabilities, such as those outlined in the lifecycle construct. While lifecycle capabilities combine technical and other organisational capabilities, embedded foundational capabilities are all organisational capabilities. More specifically, each of the embedded foundational capabilities relates to the organisational specific ways of working and the relationships between different stakeholders at ABC.

\begin{tabular}{|l|l|l|l|l|}
\hline Joint Problem Solving & Entrenching Nexus Points & Social Fusion & Open Dialogue & Knowledge Diffusion \\
\hline
\end{tabular}

Figure 2: Embedded foundational capabilities at ABC

Joint problem solving is seen as an embedded organisational capability that is used throughout the development of information systems. Working in a collaborative mode is seen to contribute to tacit knowledge and create an environment of shared responsibility and understanding.

Entrenching nexus points reflects the protection of key crossover or nexus points within working relationships between stakeholders involved in the development and use of information systems. This capability is seen as key because of the naturally occurring conflicting priorities of different stakeholders at ABC such as the conflicting priorities of information systems and business professionals.

Social fusion refers to the deliberate mixing of individuals and teams, in work and play. This capability is supported by ways of working, including physical structures and development processes, and the celebration of milestones and achievements. An innovative workplace design evident at $\mathrm{ABC}$ also embodies the social fusion by promoting balance and fun in the workplace.

Open dialogue is seen as a critical part of information technology development and use. Again, physical work structures along with collaborative ways of working contribute to high levels of communication. Such work practices build an environment of trust, respect, and understanding.

Knowledge diffusion is the last of the embedded foundational capabilities. This capability acknowledges the tacit and explicit knowledge at $\mathrm{ABC}$, which stems from internal ownership of knowledge, as well as learning from communication, experiences, training, and results. ABC's strong hold on technology helps to ensure that individual and group knowledge is retained within the organisation. Knowledge is shared through communication and ways of working, which means individual knowledge, albeit tacit, is cultivated within the organisation.

Lifecycle and embedded foundational capabilities together form an integrated model of advantage at ABC (see Figure 3). The model shows how interlinked capabilities are used in the conceptualisation, development, and use of information systems at $\mathrm{ABC}$. There are strong linkages 
between the embedded foundational capabilities and each of the lifecycle capabilities. The linkages are indicated in the figure via the dotted lines from each of the embedded foundational capabilities circling the lifecycle capabilities. This emphasises the supportive role each of the embedded foundational capabilities plays in the development of information systems at ABC.

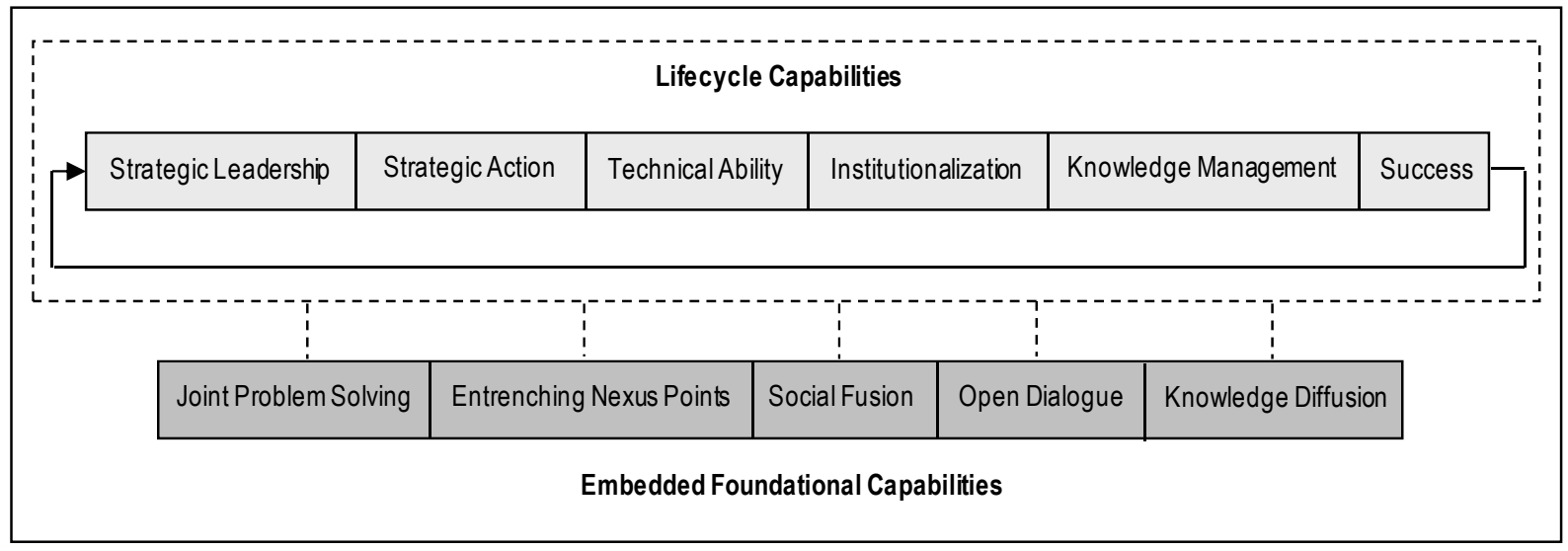

Figure 3: Integrated model of advantage at $\mathrm{ABC}$

While at one point in time the model is constrained by the firm's antecedent capability base, it also creates new resources (and therefore, alters capabilities) over time through a process of path dependant learning. That is, as each new project is undertaken and moves though the lifecycle, path dependant learning occurs, which is used to alter capabilities. While the way in which capabilities evolve is beyond the scope of this research, it is clear that learning and knowledge about each of the capabilities is valuable to ABC. Therefore, a critical part of this model is the institutional knowledge captured in each stage of the lifecycle. This research recognises such knowledge, as seen by the two occurrences of aspects of knowledge in the integrated model of advantage. Further details of such linkages can be found in Rastrick (2009).

\section{Discussion}

The findings of this research outlined many individual sources of ICT advantage. It became clear to the researchers that each of the resources enables the development of information systems at $\mathrm{ABC}$. For instance, the innovative resource is one of the individual sources of value to $\mathrm{ABC}$. Exploiting such a resource in the way $\mathrm{ABC}$ does means that it is able to generate a collaborative environment in which innovation is fostered. Development astuteness is another example of an individually valuable resource. When utilised, this resource enables the technical development of agile information systems. While all resources identified are valuable individually, they are more valuable when coupled with other organisation resources. As such, the integrated model of advantage starts to demonstrate how resources combine to form capabilities critical to the development of information systems at ABC. Each resource is coupled with other resources to form capabilities. For example, the resources 'implementation advantage', 'change management', 'marketing', and 'shared understanding' are bundled to form a capability which allows ABC to take an ICT project from a technical development to a rolled out 'live' information system (the bundle of these resources is called lifecycle capabilities). Capabilities are then coupled with other capabilities to form parts of the integrated model. The two different types of capabilities evident in the model assist in the development of information systems at ABC: lifecycle capabilities, which are more procedural capabilities utilised at different points in time throughout a project, and embedded foundational capabilities, which have an influence throughout the conception, development, 
and use of information systems at $\mathrm{ABC}$. The key story of ABC's advantage can be explained by the total ownership of technology, that is the way $\mathrm{ABC}$ utilise both lifecycle and embedded foundational capabilities in the development and use of information systems. Total ownership is directly related to the capabilities themselves (they demonstrate how $\mathrm{ABC}$ retains the capability to develop and utilise information systems) but also in the unique way $\mathrm{ABC}$ has chosen to develop technology which has built these capabilities over time (e.g., change in these capabilities and how the capabilities evolve as $\mathrm{ABC}$ continually improves its information systems).

ABC's total ownership of technology is a critical factor underpinning the integrated model of advantage. That is, ABC's decision to retain ownership and knowledge of their ICTs means that it has a pool of collective knowledge which has potential to enable a position of advantage. This finding is consistent with prior research which has also signalled the importance of ownership and knowledge (Ray et al., 2004; Ray, Muhanna, \& Barney, 2005). This means that ABC retains strategy and architectural knowledge of their ICTs at a macro level (through the lifecycle capabilities strategic leadership, strategic action, technical ability and so forth), and procedural and institutional knowledge about specific ICTs and how they combine with other ICTs is retained within the organisation (through both lifecycle and embedded foundational capabilities such as institutionalization, knowledge management, joint problem solving, entrenching nexus points, and so forth). Additionally, knowledge of the development of methodologies, ways of working, and project specific knowledge (such as knowledge of key directions and decisions of specific ICT projects) are also captured. Knowledge is thus captured in multiple ways. For example, $\mathrm{ABC}$ has technical knowledge banks of procedural practices and capability indexes outlining skills and capabilities of employees. The collaborative approach to ICT development is another way in which $\mathrm{ABC}$ captures organisational knowledge. The macro and micro knowledge outlined gives $\mathrm{ABC}$ a large potential advantage over other organisations that develop ICTs in different ways (that do not allow them to retain this knowledge).

However retaining knowledge only gives $\mathrm{ABC}$ advantage potential. To realise this potential, $\mathrm{ABC}$ combines organisational capabilities. Combinations of capabilities are achieved by utilising multiple capabilities at the same time and using an inclusive approach to the development of ICTs. Naturally, the ability to combine capabilities is strongly linked to the abovementioned ownership of ICTs as it is hard to combine capabilities that you don't own. Extensive use of teams in the development of ICTs aids in cultivating an inclusive approach. As such, many formal and informal channels of communication exist that protect and enhance relationships and knowledge sharing within teams (as reflected in the embedded foundational capabilities in the integrated model of advantage). These channels allow knowledge that is largely tacit in nature to transfer from the individual to group levels and allow the company to grow the above-mentioned level of procedural and institutional knowledge. Physical work structures also reflect the inclusive approach used at $\mathrm{ABC}$ in that they promote formal and informal interactions. Transfer of knowledge through these multiple channels and experience in developing ICTs help reinforce the knowledge base.

Three benefits of this inclusive approach are evident: better ICT solutions, a commitment to change from employees of the organisation, and organisational synergies realised. For example, there are strong levels of satisfaction evident at $\mathrm{ABC}$ regarding its recent major upgrade to its CRM solution. Such satisfaction is largely a function of the way the solution meets the organisation's needs. The inclusive approach to the development ensured that stakeholder's needs were met.

The commitment to change is built from awareness and understanding of the status of the project, what the progress is going forward, and what the different stakeholder's roles are. Supportive capabilities, such as those evident in the embedded foundational capabilities at ABC, help foster such awareness and understanding. Increasing levels of group and institutional knowledge by the 
transfer of knowledge between teams enables awareness and understanding. For instance, if one stakeholder holds project and process knowledge then change can occur. However if groups of stakeholders hold project and process knowledge then more harmonious change can occur because many are taken on the journey of change. Therefore, increasing levels of group and institutional knowledge increases levels of trust, engagement, and, most significantly, cultivates commitment to change. Furthermore, the ongoing nature of change at $\mathrm{ABC}$ helps further strengthen relationships, knowledge sharing, and the resultant knowledge base.

Synergy gained from interlinked capabilities and the inclusive approach means that the linkages between capabilities are as important as, if not more important than, each of the capabilities being present in an organisation in a non-integrated way. This is because the capabilities are coupled in such a way that the sum of all the capabilities has greater organisational value than the sum of individual capabilities. In other words, if the inter-linkages did not exist many of the benefits of the model would not be realised. For instance, if $\mathrm{ABC}$ did not form development teams, interact, communicate, and share knowledge in the ways it does, then its procedural and institutional knowledge base would be limited and would certainly not grow in the way that it does. While a development methodology could still be followed without the closeness and interactions of capabilities, the level of strategic alignment, awareness, commitment, and engagement from stakeholders would not be as strong. Moreover, the synergy implicit in the integration of capabilities means that if another organisation could imitate multiple capabilities it is not likely to see the level of advantage evident at ABC.

In summary, retaining collective strategic and operational knowledge gives $\mathrm{ABC}$ a potential advantage. To realise this potential ABC employs an inclusive approach to ICT development. The inclusive approach means that multiple procedural and enabling capabilities are utilised at the same time. The effect of this is better ICT solutions and a commitment by stakeholders who become part of a project. Organisational synergies are also realised. The end result is better performance for $\mathrm{ABC}$.

Many individual elements of the integrated model of advantage are evident in the literature. For instance, strategic alignment (Teo \& Ranganathan, 2003), internal commitment (Montealegre, 2002), teamwork (Ray et al., 2005), and knowledge (Wiklund \& Shepherd, 2003) are all individually seen as valuable in current research. Moreover, some models of interlinked capabilities are seen in other research. For instance, the integrated model of advantage compares to research which examines dynamic capabilities (Teece et al., 1997), research and development routines (Pan, Pan, \& Hsieh, 2006), systems development methodologies (Larman \& Basili, 2003), as well as different capability constructs (e.g., Savory, 2006; Tyler, 2001; Yeoh \& Roth, 1999). Each of these bodies of research outlines integration of capabilities in search of change. Evidence of links to strategy and knowledge is also evident in much of the aforementioned research and the integrated model of advantage. This research provides empirical support for current research and suggests that organisational advantages are built on interlinked capabilities that are embedded within an organisation and that exhibit elements of continuous improvement. The integrated model of advantage extends current research by outlining two constructs or different groupings of resources and capabilities that are made up of specific interlinked organisational capabilities. Differences are also introduced due to the level of detail provided in the integrated model of advantage (further outlined in Rastrick, 2009) not evident in other research.

\section{Conclusions, Limitations, and Implications for Future Research}

Given the ongoing interest and spending on ICTs in organisations there is little doubt that understanding these resources in more detail is valuable. Prior research in the area has examined po- 
tential advantages derived from ICTs relative isolation from other resources and capabilities. The research presented in this paper addresses the first research question, "What are the sources of ICT advantage?" by outlining three broad classifications of valuable resources that were seen as valuable to ABC: ICT, strategic, and human resources. While these resources were individually valuable, the total value of the resources working together is seen to be more valuable than the sum of the parts. The second research question, "How are ICTs combined with other resources to create valuable resources and capabilities?" results in an integrated model of advantage at ABC. The model outlines how two distinct types of capabilities are valuable to ABC: lifecycle and embedded foundational capabilities. The essence of the integrated model of advantage suggests that the success of $\mathrm{ABC}$ can be attributed to the complex and interlinked nature of capabilities and the inclusive approach utilised in the development of ICTs, as well as the embedded knowledge underlying each capability and the model in its entirety. Claims have been made in the literature about interconnection of resources and capabilities (conceptually) and some research is now starting to show linkages among resources or capabilities. However, research which provides distinctions between types of interconnected resources and capabilities is considered to be at an infant stage. Therefore, this research provides an early in-depth case study which identifies integrated capabilities and helps to explain why bundling them together can be beneficial to an organisation.

This research has important implications for researchers in the fields of information systems and strategic management. The research makes a contribution to information systems research by providing one of the first grounded models of integrated or interlinked ICT and other organisational capabilities. The results suggest that the total ownership of technology evident at ABC offers a potential advantage that can be realised through the integration of capabilities and an inclusive approach to ICT development. A contribution is also made to the strategic management area, which is concerned with identifying specific sources of advantage. This research empirically demonstrates that there is a strong connection between resources and capabilities (and capabilities and capabilities) in a high performing organisation. Furthermore, this research adds strength to the claims that organisational advantages are largely dependent on organisational knowledge.

The findings are based on an in-depth case study of ABC. The company was chosen due to the unique position of advantage it has in the marketplace. The research discussed the company's idiosyncratic characteristics that have impacted on its current position in the marketplace. Therefore it is likely that the findings are not generalisable to all companies in all marketplaces.

In the same way that Montealegre (2002) commented that resources and capabilities associated with his model of 'capability development' are not exhaustive, the results of this research are not intended to be an exclusive list of all aspects of ABC's advantage. Furthermore, this research made no attempt to examine in depth the link between capabilities and competitive advantage. Further research could take the capabilities identified in the integrated model of advantage and examine this.

Given the clear lack of empirical research in the area of combining capabilities, the potential for future research in this area is substantial. Building on research by Tyler (2001), which calls for more work that examines the relationships between key organisational resources and capabilities, the authors hope that this research will encourage more empirical research examining ICT resource combinations.

Finally, a significant part of ABC's advantage was found to be associated with the embedded organisational knowledge captured. Future research could examine other organisations that undertake development projects using alternative methodologies and ways of working. Such research should consider how or if the organisation (undertaking developments with significant difference) captures such knowledge. For example, further research could examine how organisational 
knowledge is captured if other development styles, such as employing extensive use of outside consultants, are utilised.

\section{References}

Barney, J. (1991). Firm resources and sustained competitive advantage. Journal of Management, 17(1), 99120.

Bharadwaj, A. S. (2000). A resource-based perspective on information technology capability and firm performance: An empirical investigation. MIS Quarterly, 24(1), 169-196.

Chan, Y. E. (2000). IT value: The great divide between qualitative and quantitative and individual and organizational measures. Journal of Management Information Systems, 16(4), 225-261.

Dewan, S., \& Kraemer, K. L. (1998). International dimensions of the productivity paradox. Communications of the ACM, 41(8), 56-62.

Eisenhardt, K. M., \& Martin, J. A. (2000). Dynamic capabilities: What are they? Strategic Management Journal, 21(10-11), 1105-1121.

Hult, G. T., \& Ketchen, D. (2001). Does market orientation matter? A test of the relationship between positional advantage and performance. Strategic Management Journal, 22(9), 899-906.

Jones, G. R., \& George, J. M. (1998). The experience and evolution of trust: Implications for cooperation and teamwork. Academy of Management Review, 23(3), 531-546.

Langley, A. (1999). Strategies for theorizing from process data. Academy of Management Review, 24(4), 691-710.

Larman, C., \& Basili, V. R. (2003). Iterative and incremental development: A brief history. Computer, June, 47-56.

Liebeskind, J. P. (1996). Knowledge, strategy, and the theory of the firm. Strategic Management Journal, 17(Winter Special Issue), 93-107.

Lin, W. T., \& Lin, H.-J. (2006). International productivity paradox of IT in commercial banking: A cost efficiency analysis. The Business Review, Cambridge, 5(1), 246-252.

Mata, F. J., Fuerst, W. L., \& Barney, J. B. (1995). Information technology and sustained competitive advantage: A resource-based analysis. MIS Quarterly, December, 487-505.

Melville, N., Kraemer, K. L., \& Gurbaxani, V. (2004). Review: Information technology and organizational performance: An integrative model of IT business value. MIS Quarterly, 28(2), 283-322.

Menon, N. M., Lee, B., \& Eldenburg, L. (2000). Productivity of information systems in the healthcare industry. Information Systems Research, 11(1), 83-92.

Miller, D. (2003). An asymmetry-based view of advantage: Towards an attainable sustainability. Strategic Management Journal, 24(10), 961-976.

Montealegre, R. (2002). A process model of capability development: Lessons from the electronic commerce strategy at Bolsa de Valores de Guayaquil. Organization Science, 13(5), 514-531.

Mooney, J. G., Gurbaxani, V., \& Kraemer, K. L. (1995). A process oriented framework for assessing the business value of information technology. Paper presented at the International Conference on Information Systems, Amsterdam, The Netherlands.

Pan, S., Pan, G., \& Hsieh, M. H. (2006). A dual-level analysis of the capability development process: A case of TT\&T. Journal of the American Society for Information Science and Technology, 57(13), 1814-1829.

Patton, M. Q. (2002). Qualitative research \& evaluation methods (3rd ed.). Thousand Oaks, California: Sage Publications, Inc.

Penrose, E. T. (1959). The theory of the growth of the firm. Oxford: Oxford University Press. 
Peteraf, M. A. (1993). The cornerstones of competitive advantage: A resource-based view. Strategic Management Journal, 14, 179-191.

Pettigrew, A. (1992). The character and significance of strategic process research. Strategic Management Journal, 13, 5-16.

Porter, M. E., \& Millar, V. E. (1998). How information gives you competitive advantage. In M. E. Porter (Ed.), On competition (pp. 75-98). Boston: Harvard Business School Publishing.

Powell, T. C., \& Dent-Micallef, A. (1997). Information technology as competitive advantage: The role of human, business, and technology resources. Strategic Management Journal, 18(5), 375-405.

Rai, A., Patnayakuni, R., \& Patnayakuni, N. (1997). Technology investment and business performance. Communications of the ACM, 40(7), 89-97.

Rastrick, K. (2009). Combining capabilities for competitive advantage: A techno savvy company's approach. Germany: VDM Verlag.

Ray, G., Barney, J. B., \& Muhanna, W. A. (2004). Capabilities, business processes, and competitive advantage: Choosing the dependent variable in empirical tests of the resource-based view. Strategic Management Journal, 25(1), 23-37.

Ray, G., Muhanna, W. A., \& Barney, J. B. (2005). Information technology and the performance of the customer service process: A resource based analysis. MIS Quarterly, 29(4), 653-672.

Rouse, M. J., \& Daellenbach, U. S. (1999). Rethinking research methods for the resource-based perspective: Isolating sources of sustainable competitive advantage. Strategic Management Journal, 20, 487497.

Savory, C. (2006). Translating knowledge to build technology competence. Management Decision, 44(8), 1052-1075.

Spender, J. C. (1996a). Making knowledge the basis of a dynamic theory of the firm. Strategic Management Journal, 17 (Special Issue), 45-62.

Spender, J. C. (1996b). Organizational knowledge, learning and memory: Three concepts in search of a theory. Journal of Organizational Change Management, 9, 63-78.

Strauss, A., \& Corbin, J. (1998). Basics of qualitative research: Techniques and procedures for developing grounded theory. United States of America: Sage Publications, Inc.

Teece, D. J., Pisano, G., \& Shuen, A. (1997). Dynamic capabilities and strategic management. Strategic Management Journal, 18(7), 509-533.

Teo, T. S. H., \& Ranganathan, C. (2003). Leveraging IT resources and capabilities at the housing and development board. Strategic Information Systems, 12, 229-249.

Tyler, B. B. (2001). The complementarity of cooperative and technological competencies: A resourcebased perspective. Journal of Engineering and Technology Management, 18, 1-27.

Wernerfelt, B. (1984). A resource-based view of the firm. Strategic Management Journal, 5, 171-180.

Wiklund, J., \& Shepherd, D. (2003). Knowledge-based resources, entrepreneurial orientation, and the performance of small and medium-sized businesses. Strategic Management Journal, 24(13), 1307-1314.

Wright, P. M., Dunford, B. B., \& Snell, S. A. (2001). Human resources and the resource based view of the firm. Journal of Management, 27, 701-721.

Yeoh, P. L., \& Roth, K. (1999). An empirical analysis of sustained advantage in the US pharmaceutical industry: Impact of firm resources and capabilities. Strategic Management Journal, 20, 637-653.

Yin, R. K. (2003). Case study research: Design and methods (3rd ed. Vol. 5). United States of America: Sage. 


\section{Appendix A - Empirical Base}

The following tables provide a description of the empirical base of this research. Table A1 outlines the number of interviewees and who the subject of the interview was.

Table A1 - Description of the interviews undertaken

\begin{tabular}{lll}
\hline $\begin{array}{l}\text { Division of the organisation } \\
\text { interviewee is from }+\end{array}$ & $\begin{array}{l}\text { Position of interviewee in the or- } \\
\text { ganisation+ }\end{array}$ & $\begin{array}{l}\text { Length of Tran- } \\
\text { script }^{\wedge}\end{array}$ \\
\hline Senior Management & Information Technology & 13 pages \\
\hline Senior Management & Information Technology & 20 pages \\
\hline Senior Management & Corporate Services & 12 pages \\
\hline Middle Management & Information Technology & 23 pages \\
\hline Middle Management & Customer Services & 24 pages \\
\hline Middle Management & Customer Services & 8 pages \\
\hline Senior Management & Customer Services & 24 pages \\
\hline Senior Management & Information Technology & 8 pages \\
\hline Senior Management & Information Technology & 12 pages \\
\hline Middle Management & Customer Services & 16 pages \\
\hline Senior Manager & Information Technology & 12 pages \\
\hline End User & Customer Services & 6 pages \\
\hline End User & Customer Services & 5 pages \\
\hline End User & Customers Services & 6 pages \\
\hline Middle Management & Information Technology & 16 pages \\
\hline
\end{tabular}

+ While the interviewees' workgroup and position was important for this research it was also important for the interviewees to remain anonymous due to the confidentiality they were ensured by the researchers. Therefore, the researchers have only identified the interviewees by division and position in the organisation not job title or name.

${ }^{\wedge}$ Length of transcript refers to the number of 1.5 lined spaced typed pages of transcript.

The researchers did not pre-determine what a suitable number of interviews would be. Instead data collection through this method was determined in the analysis stage (which was performed in parallel to data collection) once theoretical saturation was reached. Moreover, some interviewees were interviewed more than once. This is because the researchers' sensitivity to relevant phenomena grew throughout the research process; therefore, it was deemed suitable to resample some interviewees. Strauss and Corbin (1998) recommend such a strategy. In fact the researchers suggest who the interviewee is is often of less significance in the grounded theory process since the researcher's objective is not to sample people rather it is to "sample incidents, events, or happenings" (Strauss \& Corbin, 1998, p 202). The interview base (i.e., who was to be interviewed) was also not predetermined. Rather sampling occurred throughout the intertwined data collection and coding process.

Table A2 provides a summary of each of the observations undertaken in the process of carrying out this research. The table describes the setting of the observation and the length of observation.

Table A2 - Description of the observations undertaken 


\begin{tabular}{lll}
\hline Description of setting & Scope of observation & Length of observation \\
\hline $\begin{array}{l}\text { Steering Group Meet- } \\
\text { ing }\end{array}$ & $\begin{array}{l}\text { Major project stakeholders from all parts of } \\
\text { the organisation were present to discuss the } \\
\text { position of the project. }\end{array}$ & 1 hour \\
\hline $\begin{array}{l}\text { Steering Group Meet- } \\
\text { ing }\end{array}$ & $\begin{array}{l}\text { Major project stakeholders from all parts of } \\
\text { the organisation were present to discuss the } \\
\text { position of the project. }\end{array}$ & 1 hour \\
\hline End User Training & $\begin{array}{l}\text { End users of the systems were present (30) to } \\
\text { be trained by a "super users" in the use of the } \\
\text { new system pre-rollout. }\end{array}$ & 1 hour \\
\hline Workgroup Meeting & $\begin{array}{l}\text { Meeting regarding stakeholders with specific } \\
\text { needs of the new system to inform them of } \\
\text { what they can expect from the new system. }\end{array}$ & 30 minutes \\
\hline Head Office Visit (de- & $\begin{array}{l}\text { Observation of developers and end users of } \\
\text { the system shortly after implementation of the } \\
\text { velopers and end users) }\end{array}$ & 30 minutes \\
\hline pustomer Services & $\begin{array}{l}\text { Observation of end users of the system after } \\
\text { the implementation of the project. }\end{array}$ & 25 minutes \\
Visit (end users) & $\begin{array}{l}\text { Observation of the main technology develop- } \\
\text { ment centre where the project was created. }\end{array}$ & \\
\hline Development Site Visit hour & \\
\hline
\end{tabular}

Table A3 provides a summary of the documents reviewed in the process of undertaking this research.

Table A3 - Description of the documents utilised

\begin{tabular}{lll}
\hline Description of document & $\begin{array}{l}\text { Division of organisation sourced } \\
\text { from }\end{array}$ & $\begin{array}{l}\text { Length of docu- } \\
\text { ment }\end{array}$ \\
\hline Vision and Values Document & Corporate Services & 2 pages \\
\hline $\begin{array}{l}\text { HR Documentation (Corporate health } \\
\text { check) }\end{array}$ & Corporate Services & 20 pages \\
\hline Corporate Intranet & Corporate Services & Various \\
\hline Site Design (workplace) Publication & Information Technology & 29 pages \\
\hline Implementation Video & Customer Services & 8 minutes \\
\hline IT Product Video & Customer Services & 5 minutes \\
\hline Communications Video & Customer Services & 21 minutes \\
\hline Project Scoping Paper & Customer Services & 12 pages \\
\hline Project Discussion Paper & Customer Services & 23 pages \\
\hline IT Product Document & Information Technology & 66 pages \\
\hline Steering Group Meeting Agenda & Information Technology & 2 pages \\
\hline Steering Group Meeting Minutes & Information Technology & 11 pages \\
\hline Annual Reports & Company Website & Various \\
\hline Industry Reports & Industry Websites & Various \\
\hline
\end{tabular}

It is also important to note that the researchers took notes after all interviews and observation visits to $\mathrm{ABC}$. This enriched the empirical base outlined in this appendix. 


\section{Appendix B - Sample Interview Questions}

Based upon the research questions being addressed in this study, the following are examples of the types of questions used within the interviews. The exact questions varied depending on who was being interviewed and what area of the business they originated from. These questions were also expanded upon within the interview setting. This left the interviewer free to explore, probe, and ask further questions that illuminated the subject area (Patton, 2002).

\section{Scene Setting}

How is your department/division made up?

$\checkmark$ Staff Numbers

$\checkmark$ Divisions

What is your role in the organisation?
$\checkmark$ Present
$\checkmark$ Past
$\checkmark$ Time in organisation
$\checkmark$ Number of staff responsible for
$\checkmark$ Accountable to

\section{Information Technology}

What are core information systems in your area?

$\checkmark$ Customer facing and non-customer facing

$\checkmark$ Compared with others in the industry

$\checkmark$ What do you see as critical assets

How would you discuss competitive advantage in your company?
$\checkmark$ Information Technology
$\checkmark$ Human Resources
$\checkmark$ Customers perception
$\checkmark$ Benchmarking

How are new ideas generated in your company?
$\checkmark$ Top management
$\checkmark$ Information technology development team
$\checkmark$ Customer service
$\checkmark$ Customers

Are ideas on product and process improvement taken seriously?
$\checkmark$ Never
$\checkmark$ Sometimes
$\checkmark$ Always

How would you discuss your company in terms of:
$\checkmark$ Innovation
$\checkmark$ Risk-taking
$\checkmark$ Bureaucracy 
How independent are systems in your organisation?

How are IT projects initiated in your area?
$\checkmark$ Proactive
$\checkmark$ Reactive
$\checkmark$ Driven by who

How would you describe the involvement your staff have with IT development projects?

$\checkmark$ What stages are they involved in

How are information systems developed in your company?
$\checkmark$ Internally
$\checkmark$ Externally

How are IT projects concluded?

$\checkmark$ Technology review

$\checkmark$ Team review

$\checkmark$ Training

$\checkmark$ Benefits calculated

$\checkmark$ Feedback

How would you describe staff in your areas response to change?

Do staff in your area openly embrace new information technologies?

Do you have much trouble fitting information technology with the company culture?

\section{Human Resources}

Is there a staff development program in place?
$\checkmark$ Organisational wide
$\checkmark$ Divisional

How would you describe your division in terms of:

$\checkmark$ Communication and teamwork

$\checkmark$ Trust and openness

$\checkmark$ Conflict

Do staff in your area have any shared training/knowledge sharing with your parent company?

Do you think there is a shared understanding of what your department does across other divisions of the company?

Do staff in your area have an understanding of other areas of the business?

Do staff from your area participate in:
$\checkmark$ Business planning
$\checkmark \quad$ IT planning 


\section{Appendix C - Example of Grounded Theory Data Analysis}

The following is a brief example of how the grounded theory process was applied to this research. The sample provided uses an extract from a transcript from one interview, which is representative of other transcripts. Any reference which may identify the participant has been removed. Since the sample is only a brief extract it does not highlight all of the phenomena, categories, and concepts; however, the example is representative of the process used throughout the data analysis. It is important to note that all raw data collected was treated in the same way in the data analysis stage. For instance, observations undertaken as part of this research process lead to notes written as soon as practical after the observation occurred (and in some instances this was done during the observation) and then the notes were analysed in the same way in which other data such as interview transcript were, as described below.

\section{Transcript Extract}

The following extract is an example of an interview transcript in its pre-coded state, i.e., what the authors began with prior to employing the grounded theory approach to data analysis.

Uh, the senior team, the chief executive said I want to be able to do this, and as a result of that, so it was top down, we will do this. And then a lot of collaboration across functionality between... (the different divisions) .... and the technology team, about how best to do this. In fact, it was a painfully long period of time while everyone collaborated on it, because everyone kind of, once you decided to do stuff you want to get on and do it, so it kind of dragged on for a long time while we figured out the most optimum way of doing it. And the reason it took so long is because of having that good conversation between the guys in... (frontline offices) ... how were saying we want to do this way and our technology guys saying well, are you sure that makes sense that is kind of the old world, why don't we do it like this, because people don't know what they don't know. So they just want to automate what they have and so you have to kind of have this conversation with them where you stimulate business process reengineering and the like.

\section{Open Coding}

The first step in employing a grounded theory approach to data analysis is using open coding. This stage is undertaken to identify initial phenomena in the transcript. During the process of open coding the authors examine the text looking for events, objects, actions, or interactions which are considered relevant to the research.

Phenomena are identified in the below extract and are numbered and indicated in bold.

Uh, the senior team, the chief executive said (1) I want to be able to do this, and as a result of that, so it was (2) top down, we will do this. And then a (3) lot of collaboration across functionality between... (the different divisions) ... and the technology team, (4) about how best to do this. In fact, it was a painfully (5) long period of time while (6) everyone collaborated on it, because everyone kind of, once you decided to do stuff you want to get on and do it, so it kind of (7) dragged on for a long time while we (8) figured out the most optimum way of doing it. And the reason it took so long is because of having that (9) good conversation between the guys in the (10) ... (frontline offices) ...how were saying we want to do this way and our technology guys saying well, are you sure that makes sense that is kind of the old 
world, why don't we do it like this, because (11) people don't know what they don't know. So they just want to automate what they have and so you have to kind of (12) have this conversation with them where you stimulate (13) business process reengineering and the like.

Phenomena identified from the extract are labeled and listed below.

(1) Future plan

(2) Top down drive

(3) Collaboration across functionality

(4) Optimisation sought

(5) Time consuming

(6) Everyone collaborated

(7) Long time

(8) Searched for optimal way

(9) Good conversation

(10) Different visions/plans

(11) Limited foresight in other areas

(12) Two way conversation

(13) Business process reengineering

The next stage of open coding involved grouping similar phenomena and re-labeling them as concepts. This process (as it related to the small extract presented in this Appendix) is shown below. The number shown in brackets at the end of the concept names relate to the phenomena numbered in the previous step.

(A) Strategic plan (1)

(B) Leadership (2)

(C) Collaboration $(3,6)$

(D) Optimisation $(4,8)$

(E) Time intensive $(5,7)$

(F) Open dialogue $(9,12)$

(G) Conflicting plans (10)

(H) Limited external awareness (11)

(I) Business process reengineering (13)

The last stage of open coding involved comparing concepts with each other to identify similarities and differences. Concepts that were found to be conceptually similar or related are then termed categories. The list of categories (which relate to the extract presented in this Appendix) is presented below. The letters shown in brackets related to the concepts presented in the previous step.

(I) Strategic and Leadership (A, B)

(II) Ways of working (C, D, E, F, I)

(III) Conflicts $(\mathrm{G}, \mathrm{H})$

Please note: concepts and categories presented here differ slightly from labeling used in the phenomena table presented in Appendix D. The different labels reflect the evolution of concepts and categories which occurred over time.

\section{Axial Coding}

This stage of the grounded theory analysis involves starting to reassemble the data. Axial coding involves finding relationships among categories. This process occurred at a more abstract level over several months. The authors tried to recreate some of the process to illustrate the axial coding stage. Relationships among categories which relate to the open coding results (presented 
above) are presented below. The roman numerals related to the last stage of the open coding process.

Things to do with process: strategic and leadership (I) and Conflicts (III)

Things that are supportive of the process: ways of working (II)

\section{Selective Coding}

Selective coding involves integrating categories into a final theoretical scheme. Again this process (or more particularly the final theoretical scheme) evolved over several months. The primary method this researcher used in the selective coding stage was developing diagrams to examine the interrelationships between categories. An example of how a diagram would have helped undertake the selective coding process (using the data presented in this Appendix) is presented in Figure $\mathrm{C} 1$. As can be seen the diagram is not complete, rather it is indented to demonstrate how the researcher would use the limited information in this Appendix to make sense of the data.

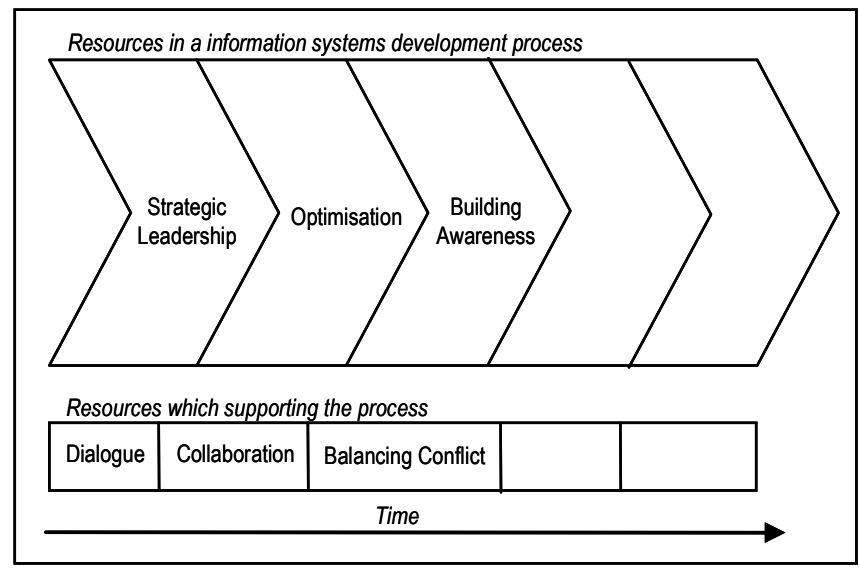

Figure C1 - Example of how a diagram could help the researcher in the selective coding stage 


\section{Appendix D - Phenomena Table}

The table presented below (Table D1) summarises the occurrences of phenomena, concepts, and categories that were created during the grounded theory analysis. Presenting data from the grounded theory analysis in phenomena tables (counts of phenomena, concepts, and categories that occurred in the raw data) involves turning qualitative data into a more quantitative form. While this is not completely desirable, since the researcher undertook a qualitative approach, in this case the phenomena table provided another supporting tool to discuss the results of the research. The phenomena table presented below was created from the raw data gathered in the interview process. While other data collection approaches were also utilised in this research, data from such sources are not reflected in the phenomena table.

Table D1 - Summary of interview data

\begin{tabular}{|c|c|c|c|c|c|}
\hline Category & Concept & Phenomena & $\begin{array}{c}\text { IT Occur- } \\
\text { rences + }\end{array}$ & $\begin{array}{c}\text { Business } \\
\text { Occurrences } \\
\wedge\end{array}$ & $\begin{array}{l}\text { Total Oc- } \\
\text { currences }\end{array}$ \\
\hline \multirow{4}{*}{$\begin{array}{l}\text { Strategic } \\
\text { Advantage } \\
(46)^{*}\end{array}$} & \multirow{2}{*}{ Group Strategy } & Vision/Planning & 6 & 1 & 7 \\
\hline & & Alignment & 5 & 4 & 9 \\
\hline & \multirow{2}{*}{$\begin{array}{l}\text { Divisional Strat- } \\
\text { egy }\end{array}$} & Vision/Planning & 24 & 2 & 26 \\
\hline & & Awareness & 4 & 0 & 4 \\
\hline \multirow{21}{*}{$\begin{array}{l}\text { Human } \\
\text { Resource } \\
\text { Advantage } \\
(105)^{*}\end{array}$} & \multirow[t]{14}{*}{ Culture } & Pride & 6 & 1 & 7 \\
\hline & & Low turnover & 6 & 4 & 10 \\
\hline & & Engaged & 5 & 2 & 7 \\
\hline & & Open & 5 & 5 & 10 \\
\hline & & Balance & 5 & 9 & 14 \\
\hline & & Passion & 4 & 1 & 5 \\
\hline & & Trust/respect & 3 & 1 & 4 \\
\hline & & Set up for success & 3 & 3 & 6 \\
\hline & & Belief & 2 & 2 & 4 \\
\hline & & Motivated & 2 & 1 & 3 \\
\hline & & Teamwork & 1 & 4 & 5 \\
\hline & & Understanding & 1 & 1 & 2 \\
\hline & & Shared vision & 0 & 4 & 4 \\
\hline & & Supportive/caring & 0 & 1 & 1 \\
\hline & \multirow{6}{*}{$\begin{array}{l}\text { Staff Develop- } \\
\text { ment }\end{array}$} & Mentoring/encouragement & 4 & 0 & 4 \\
\hline & & Aware of needs & 1 & 2 & 3 \\
\hline & & Relationship management & 1 & 0 & 1 \\
\hline & & Continuously develop & 0 & 3 & 3 \\
\hline & & Training & 0 & 1 & 1 \\
\hline & & Talent spotting & 0 & 1 & 1 \\
\hline & $\begin{array}{l}\text { Change Man- } \\
\text { agement }\end{array}$ & Embrace Change & 7 & 3 & 10 \\
\hline \multirow{14}{*}{$\begin{array}{l}\text { IT Advan- } \\
\text { tage (464)* }\end{array}$} & \multirow{4}{*}{$\begin{array}{l}\text { Leadership and } \\
\text { Vision }\end{array}$} & Awareness & 15 & 7 & 22 \\
\hline & & Personal traits & 9 & 0 & 9 \\
\hline & & Vision/goals & 9 & 13 & 22 \\
\hline & & Managing resources & 7 & 0 & 7 \\
\hline & \multirow{3}{*}{$\begin{array}{l}\text { Innovation and } \\
\text { Continuous De- } \\
\text { velopment }\end{array}$} & Process & 28 & 7 & 35 \\
\hline & & Strive for & 18 & 9 & 27 \\
\hline & & Risks & 7 & 0 & 7 \\
\hline & \multirow[t]{4}{*}{ Relationships } & Collaboration & 13 & 0 & 13 \\
\hline & & Good rapport & 7 & 0 & 7 \\
\hline & & Cross functional teams & 3 & 0 & 3 \\
\hline & & Strong internal links & 0 & 1 & 1 \\
\hline & \multirow[t]{3}{*}{$\begin{array}{l}\text { Shared Under- } \\
\text { standing }\end{array}$} & $\begin{array}{l}\text { Business/IT work interac- } \\
\text { tively }\end{array}$ & 3 & 0 & 3 \\
\hline & & Internal transfer & 3 & 1 & 4 \\
\hline & & $\begin{array}{l}\text { Roles and process under- } \\
\text { standing }\end{array}$ & 2 & 0 & 2 \\
\hline
\end{tabular}




\begin{tabular}{|c|c|c|c|c|}
\hline \multirow{7}{*}{$\begin{array}{l}\text { Knowledge Man- } \\
\text { agement }\end{array}$} & Longevity of staff & 4 & 0 & 4 \\
\hline & Capability index & 1 & 0 & 1 \\
\hline & Knowledge sharing & 0 & 11 & 11 \\
\hline & Lesson sharing & 2 & 0 & 2 \\
\hline & Learning from experience & 0 & 6 & 6 \\
\hline & Sharing with parent & 2 & 0 & 2 \\
\hline & External partners & 5 & 1 & 6 \\
\hline \multirow{5}{*}{$\begin{array}{l}\text { Development } \\
\text { Astute }\end{array}$} & Mask complexities & 4 & 0 & 4 \\
\hline & Agility & 3 & 0 & 3 \\
\hline & Rapid development & 3 & 0 & 3 \\
\hline & Test processes & 1 & 0 & 1 \\
\hline & Business awareness & 1 & 0 & 1 \\
\hline \multirow{8}{*}{$\begin{array}{l}\text { Implementation } \\
\text { Advantage }\end{array}$} & Review/debrief & 16 & 8 & 24 \\
\hline & Delivery & 12 & 23 & 35 \\
\hline & Communication & 9 & 31 & 40 \\
\hline & Engaged & 7 & 2 & 9 \\
\hline & $\begin{array}{l}\text { Specialist knowledge } \\
\text { groups }\end{array}$ & 4 & 0 & 4 \\
\hline & Alignment & 4 & 7 & 11 \\
\hline & Awareness & 3 & 17 & 20 \\
\hline & User involvement & 2 & 2 & 4 \\
\hline \multirow[t]{4}{*}{ Functionality } & Product & 8 & 5 & 13 \\
\hline & Result of product & 7 & 7 & 14 \\
\hline & Volume advantage & 5 & 0 & 5 \\
\hline & IT and good people & 7 & 0 & 7 \\
\hline \multirow[t]{3}{*}{ Perception } & Ahead & 8 & 1 & 9 \\
\hline & Halo effect & 1 & 0 & 1 \\
\hline & First mover & 1 & 0 & 1 \\
\hline Success & External & 22 & 16 & 38 \\
\hline \multirow[t]{11}{*}{ History } & $\begin{array}{l}\text { CEO Technology back- } \\
\text { ground }\end{array}$ & 1 & 1 & 2 \\
\hline & First mover, quick learner & 1 & 1 & 2 \\
\hline & IT loyalty & 1 & 0 & 1 \\
\hline & IT enabler & 1 & 0 & 1 \\
\hline & Organic growth & 1 & 4 & 5 \\
\hline & Total ownership of IT & 0 & 4 & 4 \\
\hline & No retrenchment & 0 & 2 & 2 \\
\hline & Independence from parent & 0 & 1 & 1 \\
\hline & Origins small regional & 0 & 1 & 1 \\
\hline & $\begin{array}{l}\text { Legacy of culture reinforc- } \\
\text { ing }\end{array}$ & 0 & 3 & 3 \\
\hline & $\begin{array}{l}\text { Confidence from experi- } \\
\text { ence }\end{array}$ & 0 & 1 & 1 \\
\hline
\end{tabular}

* The number in brackets beside the category names represents the total number of occurrences of this category seen in the raw data.

+ 'IT occurrences' identifies the number of phenomena identified from interview transcripts of interviews where the interviewee was based in an information technology orientated role within ABC.

$\wedge$ 'Business occurrences' identifies the number of phenomena identified from interview transcripts of interviews where the interviewee was based in a business orientated role within ABC.

Please note: the development of concepts and categories and hence the final model presented in this research evolved over several months, however the phenomena table presented above was only developed at one point and time. The researcher favoured visual depictions of the data to help make sense of the research findings. Therefore, multiple diagrams were developed over time as the researcher made sense of the data. 


\section{Biographies}

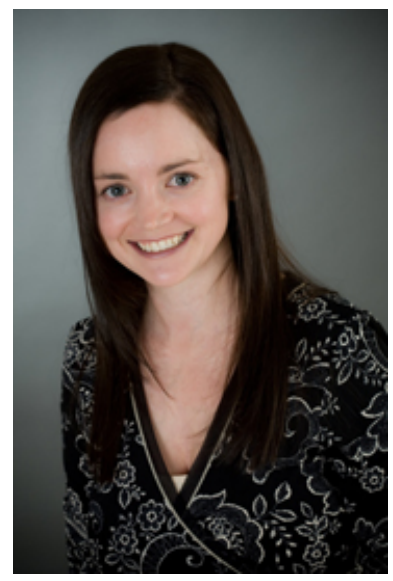

Karyn Rastrick holds a PhD from The University of Waikato in Hamilton, New Zealand. She currently serves as a Lecturer in the Department of Management Systems at The University of Waikato Management School. Her research interests include understanding information communication technologies in organisations, innovation management, and the management of critical incidents.

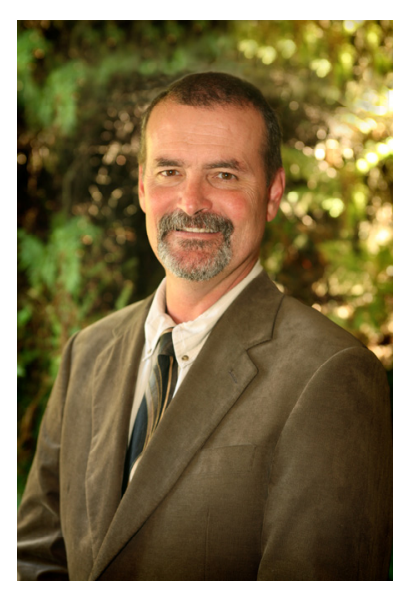

James Corner obtained his $\mathrm{PhD}$ in operations research from Arizona State University in 1991 after completing an engineering degree at the University of Virginia and an MBA from Wyoming. He also has 10 years of managerial work experience with Texas Instruments and US Steel. His research interests historically have centered around both descriptive and prescriptive decision processes, and more specifically decision analysis. He recently has expanded his interests to include knowledge management and the new field of systems intelligence. 